\title{
Liberated Bodies and Saved Souls: Freed African Slave Girls and Missionaries in Egypt
}

\author{
Beth Baron
}

In early March 1887 twelve freed slave girls arrived at the Ezbekiah Boarding School run by American Presbyterian missionaries with fifty pounds and forty yards of calico for dresses. ${ }^{1}$ They had been sent by Sir Evelyn Baring (Lord Cromer), the British agent and consul-general in Egypt from 1883 to 1907, from the Cairo Home for Freed Female Slaves, where they had been temporarily lodged. ${ }^{2}$ The dozen girls had been intercepted by British boats on the Red Sea or Egyptian police in caravans coming over land into Egypt ten years after the slave trade had been officially banned into and through the country and a few years before slavery itself became illegal. Their paths into slavery varied; their path out brought the dozen young girls together.

The enslaved in Egypt and the Islamic Middle East were mostly illiterate and left few memoirs. The lack of slave narratives and "silence of slaves" have led to an absence of voices, faces, and names of slaves from historical accounts. Scholars have recently begun to rectify this omission through innovative methodologies and literary strategies. Ehud Toledano argues, "by exploring the available options, the dilemma at hand, and the choice made by the enslaved, we can see agency and resistance emerge out of misery and powerlessness", as he focuses on the relationship that bound the enslaved and slavers. Eve Troutt Powell analyzes memoirs that have come to light, critically reading texts and raising issues about voice and memory. ${ }^{3}$ The search for new sources-visual

1 This article has been published first in African Communities in Asia and the Mediterranean: Identities between Integration and Conflict, ed. Ehud R. Toledano (Trenton, NJ: Africa World Press, 2011), 215-235.

2 Presbyterian Historical Society (PHS), Anna Thompson Papers, RG 58, box 1, folder 4, Notebook: Red Letter Days: 57, 59. The event is noted as occurring on March 1 and March 7 .

3 Ehud R. Toledano, As If Silent and Absent: Bonds of Enslavement in the Islamic Middle East (New Haven: Yale University Press, 2007); idem, Slavery and Abolition in the Ottoman Middle East (Seattle: University of Washington Press, 1998); John Hunwick and Eve Troutt Powell, The African Diaspora in the Mediterranean Lands of Islam (Princeton: Markus Wiener Publishers, 2002); Y. Hakan Erdem, Slavery in the Ottoman Empire and Its Demise, 1800-1909 (New York: St Martin's Press, 1996). 
and literary-continues alongside efforts to push theoretical understandings of slavery in the Middle East.

American missionaries were prodigious writers who kept careful records. Through years of study and practice, they mastered Arabic, and their long residences in the field (sometimes for decades) running a network of educational, medical, and welfare institutions gave them impressive knowledge of their host country. They also came with their own religious and racial baggage, which must be carefully unpacked when examining the records they left of encounters with freed slaves. These records can be read critically to get at the lives and choices of the dozen African girls who landed on their doorsteps. The story of these girls provides a look at the paths into and out of slavery, drawing attention to the youth of most of those caught in the net of the slave traders and destined for service in the Ottoman Empire.

Scholars have debated the demise of slavery in Egypt and the fate of freed slaves. The question of the demise of slavery, and whether it ended with a whimper or a bang from internal or external pressures, is tied to views of the importance of slavery in Egyptian society. Gabriel Baer tends to discredit the efficacy of bans on the slave trade enacted from the 185 os by OttomanEgyptian governors and credits the British for effectively ending the trade; he finds that the presence of guilds and absence of a free labour market hampered the absorption of freed slaves into the Egyptian society and economy. Judith Tucker sees slavery fading out more naturally. "Never of signal importance in the country, the institution slowly crumbled", as over the course of the century the significance of female slaves, who were the majority, became "ever more symbolic". Slavery "swiftly became an anachronism" and was abolished with ease. "Once the supply was cut off, and slaves could seek manumission freely, the institution in Egypt died a painless death". Tucker claims that manumitted slave women were easily assimilated "into the very classes that had formerly possessed them", with race and an earlier slave status holding no stigma. ${ }^{5}$

Other scholars occupy a middle ground. Liat Kozma, focusing on legal and police records, has sketched the abolition of the slave trade through numerous bans "as a long process of readjustment" in which the Ottoman-Egyptian legal system moved from the Islamic sanction of slavery to the "suppression of the slave trade as unjust and inhumane". In the process, "[s]laves came to be seen

4 Gabriel Baer, "Slavery in Nineteenth Century Egypt," Journal of African History 8, no. 3 (1967): 417-441; reprinted as "Slavery and Its Abolition," in Studies in the Social History of Modern Egypt (Chicago: University of Chicago Press, 1969), chap. 10.

5 Judith E. Tucker, Women in Nineteenth-Century Egypt (Cambridge: Cambridge University Press, 1985), 191-192. 
more as persons and less as property". ${ }^{6}$ Powell, looking at literary accounts and the press, sees slavery as of signal importance in Egypt's complicated colonial relationship to the Sudan. She notes the difficulty of letting go of an institution that was central to conceptions of family and intimacy, and her examination of a famous slave trading trial in 1894, which implicated leading notables, highlights this. ${ }^{7}$ For Toledano, Powell, and Kozma, race mattered, and freed slaves, most of whom were of African origins, struggled with marginality, vulnerability, and limited choices. ${ }^{8}$

In this chapter, I will show that at least in the case of the twelve enslaved African girls, and reasonably also beyond that small group, the end of slavery was neither swift nor painless. Freed slaves' attempts to shape their own lives must be seen in this context.

\section{1 \\ Memories of Home and Capture}

In the period in which the American Presbyterian missionaries established a network of institutions in Egypt, the slave trade spiked, particularly during the cotton boom of the 186os, when Egyptian cotton replaced the American commodity on the market. Slaves were brought in as a result of the wealth flooding the country from cotton profits as well as for agricultural slavery in the south. Most were domestic slaves (concubines and/or servants) in a system that did not reproduce itself and thus needed a constant influx of new slaves. The girls who landed in the Ezbekiah Boarding School ranged in age from eight to fourteen, consistent with Reda Mowafi's observation that the largest proportion of slaves imported into Egypt were under fifteen. Traders preferred younger slaves because they fetched a higher price, needed less food, and were less likely to resist during their transport. Those eleven to fourteen or fifteen were the most expensive, primarily because at that age they were young enough to be

6 Liat Kozma, "Women on the Margins and Legal Reform in Late Nineteenth-Century Egypt, 1850-1882" (PhD diss., New York University, 2006).

7 Eve M. Troutt Powell, A Different Shade of Colonialism: Egypt, Great Britain, and the Mastery of the Sudan (Berkeley: University of California Press, 2003).

8 See also Beth Baron, Egypt as a Woman: Nationalism, Gender, and Politics (Berkeley: University of California Press, 2005), chap. 1; Imad Hilal, Al-Raqiq fi Misr fi al-qarn al-tisa' 'ashar (Cairo: al-Aarabi, 1999); Hilal, "The Anti-Slavery Movement in Egypt in the Nineteenth Century: Between Shari'a and Practice" (paper presented at a workshop on "Race and Slavery Between the Middle East and Africa," Cuny Graduate Center, April 23, 2004); Reda Mowafi, Slavery, Slave Trade, and Abolition Attempts in Egypt and the Sudan, 1820-1882 (Stockholm: Esselte Studium, 1981). 
trained within a family to be a good servant but old enough to start working and engage in sexual activity, even if unwanted. ${ }^{9}$ In any case, the girls taken in by the missionaries were definitely old enough to have memories of family and home.

The origins of the twelve were never precisely recorded. A British abolitionist who visited them in the school and heard them sing some hymns "in their own language" claimed the girls came from "Galla country". ${ }^{10}$ (Today "Galla" is considered a pejorative term for the Oromo, who are mostly found in Ethiopia, formerly called Abyssinia.) But Anna Thompson, an American Presbyterian missionary who worked in Egypt from 1872 to 1932, noted a few years after the girls had come to the school, "there were Nubians among them, Soudanese and Abyssinians". ${ }^{11}$ Later, in an anonymous pamphlet on one of the freed slaves produced in the 193os or so, they are listed as seven Ethiopians and five Sudanese; Abyssinians became Ethiopians, and the Nubians were folded into the Sudanese. ${ }^{12}$ The native tongues that they claimed, and the language in which they spoke to one another are not clear.

One of the girls, named Susan, was from Nubia, according to Thompson:

In her inimitable way, after some weeks, she told how she had been carried away with her family and villagers by the Mahdi and his troops, and how she used to play with the Mahdi's children ... Her singing about the Mahdi and the white "hat owners" (English troops) as she learned it at Khartoum, was always listened to with pleasure and sadness, and she and two others could dance in the very peculiar Soudanese style. ${ }^{13}$

Susan had clear memories of home that came through in her singing and dancing, though the latter was suppressed as she became socialized into proper Christian behavior at the boarding school. The missionary teacher, Adela Brown, reflected on the summer of 1890 when Susan and one or two of the other girls stayed at the school in Cairo, unable to go home to relatives as the Egyptian girls had. Missionaries and government officials made no attempt to return these girls to their native villages, but their longing was apparent. "I heard from

\footnotetext{
9 Mowafi, Slavery, 37.

10 "Egypt," Anti-Slavery Reporter (March-April 1893), 63.

11 Anna Y. Thompson, "Mission Work in Egypt," Women's Missionary Magazine 5, no. 3 (October 1891): 68 .

12 Halima-The Gentle One (Pittsburgh: Women's General Missionary Society, United Presbyterian Church of North American, n.d.), 7 .

13 Thompson, "Mission Work," 68.
} 
them many interesting items about their native land. It was their delight to talk about ther [sic] parents and home and country. They seemed to have vivid pictures in their minds, but whether they were fancy or real I cannot say". ${ }^{14}$ The girls had strong memories of home that they liked to relate, and they listened to one another's stories and songs.

By contrast, another girl, Halima, seemed to remember little, though she was thought to be about eleven years old when she arrived at the boarding school. "Years later when questioned by friends, she could tell little of her early life," recorded her pamphleteer. She may have remembered little or may have found the memories too painful and chose to bury them deep inside. She did remember her village home in the mountains of Ethiopia in the western part of the country; the village name; and a war, in the midst of which she and some other girls were snatched while at play near the village. She did not know by what route she had been brought to Egypt, so the pamphleteer had her brought her up the Nile on a boat, rescued, and put on a train for Cairo. (The "Galla girls" had been intercepted by a British ship on the Red Sea-thus earning the name "Red Sea waifs" - and disembarked at Port Suez, where they were transferred to Cairo. Some of these girls ended up at the Ezbekiah boarding school.) Halima was a child when she was taken from her family and shipped to Egypt. The pain of that separation stayed with her, as Halima related, "I cried for my mother whenever I was awake, for a year". ${ }^{15}$

Susan seems to have been displaced twice, once with her family from Nubia to Khartoum and once on her own. She remembered being at play with another child, "getting gum from a tree", when a man on horseback carried her off. She was then passed from one person to another until she was captured by the police in Egypt. ${ }^{16}$ Her route into Egypt could have been a desert caravan led by Bedouins, who smuggled slaves to Asyut to avert bans on the slave trade. The Egyptian police force had turned from protecting owners' property rights and returning runaway slaves to enforcing the bans on the slave trade, mirroring a shift in the Ottoman Empire, where government officials had come to side with the enslaved more than the enslavers. ${ }^{17}$

The girls' memories of their homes and families come through the filter of missionary writings. At times the girls seemed eager to speak to Americans about their pasts; at other times they withheld their stories and sought to

\footnotetext{
14 A.A. Brown, "Susan Ameen," Cairo, November 1891 in Women's Missionary Magazine 5, no. 6 (January 1892): 166-167.

15 Halima, 3-4, 7; "Egypt," Anti-Slavery Reporter (March-April 1893), 63.

16 Thompson, "Mission Work," 68.

17 Kozma, "Women on the Margins," chap. 3; Toledano, Silent and Absent, chap. 3.
} 
repress painful memories. The missionaries passed on only tidbits, weaning out pieces of the story and dismissing parts as childish fantasies.

Both the slave traders and missionaries sought to redefine the religious identities of the girls. The missionaries claimed that the girls were given "Mohammedan names" by the slave traders. By making this claim, the missionaries pointed to the recent and coercive nature of their conversion to Islam. At some point during the transport of their human cargo, slavers converted the enslaved to Islam in preparation for their sale in Egypt and often gave them new names to signal their new religious identity. ${ }^{18}$ By Islamic law, the enslaved were meant to be non-Muslims captured in war, but most were captured in raids, not war, and some were already Muslims. The missionaries allowed them to keep their names, whether given by parents or slavers, except in cases of repetition. The smaller of the two Mariseela's became Seela; and the smaller of the two Taroonga's became Susan, to evoke Aswan. ${ }^{19}$ Those named in the sources (like Susan and Halima) have only first names; there are no second or father's names. The erasure of family ties transforms the girls into orphans, which is how they are labeled and treated. Few of the other freed slave girls were named at all, and not naming is also significant. They were blank slates, ready for redemption in life or death.

\section{$2 \quad$ Rescue and Manumission}

Missionaries, British abolitionists, colonial officers, Egyptian government officials, slave traders, and the enslaved were all caught up in a contentious battle over slavery. The lines in this battle were not clearly drawn. Egyptians had mixed views on slavery: those against the practice realized that stripping the Sudan of her population undermined Egyptian colonial ambitions and civilizing mission, ${ }^{20}$ that the slave trade as currently practiced contravened Islamic law, and that wage labour ultimately made more economic sense than slavery. But others profited from the trade, considered the slaves they owned assets that enhanced their prestige, saw slavery itself as civilizing and sanctioned by Islam, and could conceive of no alternative for domestic service. Said, governor

18 John Hunwick, "The Religious Practices of Black Slaves in the Mediterranean Islamic World," in Slavery on the Frontiers of Islam, ed. Paul E. Lovejoy (Princeton: Markus Wiener Publishers, 2004), 149-171.

19 Thompson, "Mission Work," 68.

$20 \quad$ For more on this, see Sara Pursley, "From Civil War to Civilizing Mission: American Military Officers in the Egyptian Service, 1869-1879" (paper presented at a workshop on "Race and Slavery Between the Middle East and Africa," CunY Graduate Center, April 23, 2004). 
of Egypt (1854-1863), had banned the slave trade in 1854; but in the absence of instruments to enforce it, the ban had been generally ineffective in stopping the slave trade, though it began to change the way the legal system conceptualized slaves. ${ }^{21}$

With the end of slavery in America, British abolitionists turned their attention to slave practices in the Ottoman Empire and pushed for stricter treaties. The Anglo-Egyptian convention of 1877 outlawed the import and export of Abyssinian and Sudanese slaves, setting up four manumission bureaus throughout Egypt to supply documents as well as find work for freed slaves and schools for freed children. Banning the slave trade when owning slaves was still legal proved difficult to enforce, especially when traders frequently passed off slaves as family members or as servants. The British, who used anti-slavery sentiments in England to mobilize support for their occupation of Egypt in 1882 and continued colonial presence, were afraid to tackle Islamic law and practices head on and moved slowly in outlawing slavery itself.

The outlawing of the slave trade when the demand for domestic slaves remained made life for smuggled slaves more precarious, as traders took detours and risks to avert the watchful eyes of agents. Officials plugged one hole only to find slaves brought into Egypt through another route. One such avenue was the importation of slaves by pilgrims returning from Mecca. It was a tempting and lucrative trade, with a high mark-up: in the mid-188os female slaves could be purchased in Mecca for about four pounds and sold in Egypt for thirty. ${ }^{22}$

Officials sought to stop the smuggling of slaves by returning pilgrims after the prohibition of the sale of slaves from family to family had gone into effect. Lieutenant-Colonel Schaefer, Director of the Slave Department, sent instructions to the commander at Port Suez in 1886. All pilgrims arriving at Suez, where most either disembarked from vessels or continued through the canal, were to be checked. Newly brought slaves without manumission papers were to be taken from their masters and sent to the Cairo Home for Freed Women Slaves established the previous year; newly brought slaves with manumission papers were to be given a choice whether they wanted to stay with their masters or not (some may have been married to their masters.) "If they are under 14 years," he instructed, "it is better to send them to Cairo." The guidelines for pilgrims traveling by ship were slightly different: "If bought recently and not over 12 years of

\footnotetext{
21 Kozma, "Women at the Margins," chap. 3.

22 E. Crewe, "The Slave Trade in Egypt," Cairo, April 9, 1886 in Anti-Slavery Reporter (MayJune 1886), 61.
} 
age, they are to be brought on shore and sent to Cairo". ${ }^{23}$ Schaefer also instructed the commander at Suez to keep a record of "all negresses or Abyssinians coming in", showing their names, masters if recently purchased or simply traveling, and what was done with them.

Schaefer wrote Baring, "I can assure you that not a single colored person has been allowed to be passed without our getting satisfactory explanations about her position". ${ }^{24}$ Note that he writes "her position", acknowledging that most of the "black or Abyssinian, male and female" who came before government officials were girls or women. Some 119 persons were checked at the police office, and forty-one were found to have been purchased in Jidda. Five or possibly seven had no manumission papers and were taken from their masters and sent to the Home for Freed Slaves in Cairo. Those sent to the Home included a Halima, who was owned by Mustapha al-Minyawr, and a Trongue, owned by Sitt Agouche, showing both male and female ownership. Both Halima and Trongue were listed as Sudanese but no ages were given. ${ }^{25}$ These girls may have been those of the same name who later landed in the missionary school, though there is some discrepancy on origin, since the Halima previously mentioned was Abyssinian.

By whatever route they had come into Egypt, both the Halima and Susan who were later raised and schooled by the missionaries had first been sent to the Home for Freed Women Slaves in Cairo. That home had been opened in January 1885 as the product of a joint effort by a committee in London associated with the British and Foreign Anti-Slavery Society (BFASs), which raised funds through subscriptions for the refuge, and a second committee in Cairo, presided over by Baring, which dealt with the logistics. Abolitionists argued that freed male slaves could find ready employment (indeed many ended up in the army) but that freed female slaves would turn to a life of vice and prostitution to survive. This assumption stemmed from a belief that Africans were prone to sexual excess and crime unless properly supervised. The lack of such a home was thought to have impeded the emancipation of slaves and enforcement of the convention of 1877 . Toward that end, Sarah Amos, a feminist, activist, and abolitionist, was one of the main advocates and organizers of the

23 Rhodes House Library, British and Foreign Anti-Slavery Society, S22, G25, Africa, No. 4 (1887), Correspondence Respecting Slavery in Egypt, Enclosure 2 in No. 1, LieutenantColonel Schaefer to Captain Crawford, Commandant, Suez, October 25, 1886, 4.

24 Ibid., Enclosure 1 in No. 1, Schaefer to Sir E. Baring, Cairo, December 16, 1886, 3.

25 Ibid., Enclosure 3 in No. 1, Schaefer, "Etat Nominal des Esclaves importes pendant le Saison du Pelerinage de 1886," 5 . The list includes question marks next to two names: Halima and Sabah. 
Home, getting it started in the neighbourhood of Faggala and setting up Mrs. Crewe, an Englishwoman who spoke fluent Arabic, as matron. ${ }^{26}$ Crewe's fluency in Arabic would have helped in communication with those slaves who had been resident in Egypt for some time but not the newly enslaved, fresh from Africa.

The Home for Freed Slaves in Cairo acted as a refuge, staging area, and referral agency, and was part of Baring's agenda to turn freed slaves into a pool of waged female labourers or domestic servants. The newly freed slaves first had to be outfitted. Accompanied by a veteran from the Home, they purchased materials in town and returned to the home for sewing instruction, "for strange as it may seem, many of the black girls absolutely do not know how to use a needle", reported the secretary to the Cairo Committee for the Freed Slaves' Home. In this way, in 1886 alone over 6 oo dresses plus other garments were cut. Once outfitted, many of the freed slaves did not stay long. Mrs Crewe helped place them in homes as domestic servants, and they were quickly snatched up, for demand for such servants exceeded supply. Initial reports suggest that the freed slaves were placed with Christian Syrians and Copts, but subsequent ones show that most were placed "in English families, others in French or Italian, and a few in native families of well-known respectability". Turn-around time was sometimes as fast as a few days. ${ }^{27}$ In short, the English were eager to turn slaves into paid domestic servants and became the first beneficiaries of this policy.

When Colonel Scott-Moncrieff, son-in-law of the chairman of the BFAss and a Cairo committee member, visited the Home in October 1885, he found that three of the nine or ten inhabitants of the home were children. Mrs. Crewe, who lived in the Home with her husband and children, claimed she could easily get these girls employment but preferred to train them herself to be good servants. ${ }^{28}$ The following year, sixteen Abyssinian girls_- "all young, and some quite little girls", entered the home together, having been intercepted from pilgrims returning from Mecca. None of the girls spoke Arabic, which was taken as a sign that they had been recently and illegally enslaved. According to E. Crewe, the children had been transported by two slave traders: six girls

26 For background on the Home for Freed Slave Women, see the Anti-Slavery Reporter (January 1885), 259; (August 1885), 449-45o; (May-June 1886), 57-58; Diane Robinson-Dunne, The Harem, Slavery and British Imperial Culture: Anglo-Muslim Relations in the Late Nineteenth Century (Manchester: Manchester University Press, 20o6), 84-92.

27 M.S.P. Du Port, "Report of the Cairo Committee for the Year 1886," in Anti-Slavery Reporter (March-April 1887), 69.

28 C. Scott-Moncrieff, letter, Cairo, October 6, 1885 in Anti-Slavery Reporter (December 1885), 595 . 
(and one boy) by Ali Pasha Wahba and ten girls (one boy, and two eunuchs) by the head of the Egyptian pilgrim caravan. In the subsequent six months, two of the new sixteen children were "sent out to service", one was married, and thirteen remained at the Home. Of those thirteen, the seven youngest went to Miss Whately's Mission School, which had been set up by the British missionary for poor children. ${ }^{29}$ The annual report for the Home for 1886 noted that nearly all the Abyssinian girls were "in service, some of them earning over L 1 per month". Six of the youngest had learned to read Arabic, and it was hoped that some might become monitors or teachers in Miss Whately's School. ${ }^{30}$

The youngest of these children, along with others, were included in the total number of children in the Home for 1886: "There are at present about twelve young children, from five to twelve years of age, in the HOME, some of whom have been rescued from Slave-dealers who were bringing them to Cairo to sell as Slaves." These girls received domestic training, in a set regime of household work, sewing, and ironing, "until such a time as they can earn their own livelihood". ${ }^{31}$ These twelve were sent to the American missionary boarding school in Cairo. They may have been sent when space became an issue: 225 slaves passed through the home in 1886, with 215 being placed in homes, and an average of fifteen to twenty occupants at any one time. The Home for Freed Women Slaves in Cairo was simply not equipped to care for young girls on a long-term basis; they would have taken up room and cost money to feed, house, and educate. The home was run on a relatively small budget, with some suggesting that it support itself, leading to a plan to utilize the labour of its inmates in laundry work. The small-scale operation was only marginally profitable, and the young girls could not contribute meaningfully to this plan or to their upkeep. ${ }^{32}$

Halima, Susan, and the others may have been sent away for another reason as well. According to the Convention of 1877 , freed slave children were to be educated, and the youngest had gone to Miss Whately's School. But the close association of girls in the Home with the missionary enterprise might have posed problems for Baring, who served as both president of the Home and British consul-general. The Home had to refrain from proselytizing among those who sought shelter, a condition the Cairo committee imposed on the project in

29 C.C. Scott-Moncrieff, "The Treasurer's Report-1886," Anti-Slavery Reporter (May-June 1886), 58; Crewe, "Slave Trade in Egypt," 61.

30 Du Port, "Report," 69; Mary L. Whately, Letters from Egypt to Plain Folks at Home (London: Seeley, Jackson, \& Halliday, 1879), 240-257; Charles C. Starbuck, "Theological and Religious Intelligence," The Andover Review (May 1889): 529 .

31 Du Port, "Report," 69.

32 Du Port, "Report," 68-69. 
order to make it acceptable to the Egyptian government, which gave the Home a 250 pound subvention. The question of slavery was controversial enough without adding religious conversion into the mix. Sending the girls to another location removed responsibility from the Home.

\section{Education and Redemption}

American missionaries who arrived in Egypt in the 1850s targeted Cairo and Asyut, a town in Upper Egypt with a large Coptic population thought to be receptive to Protestantism. Asyut was also a major depot in the slave trade and the destination for caravans on the "forty days road" (darb al-arba in) from Darfur. By coincidence, the American Mission School was situated close to the spot where the slave caravans to Asyut came to rest. ${ }^{33}$ Most American missionaries in Egypt came from northern states such as Pennsylvania, Ohio, and Illinois. They had seen battles over slavery split their country and church, giving rise to the United Presbyterian Church of North America (UPCNA), founded in $185^{8}$. The UPCNA had a strong abolitionist platform and opened "freedmen's missions" after the American Civil War. But Americans in Egypt were there to save Egyptian souls, not to free African slaves, and treaded carefully. ${ }^{34}$ Still, when opportunities presented themselves, they intervened, pressuring Copts to free their own slaves, alerting consuls to slave caravans, and giving refuge to rescued slaves. ${ }^{35}$ The missionaries benefited from their interventions. The first Muslim convert was an unnamed freed slave who joined the church in 1866 , and twenty-two of the thirty-nine Muslims who had been baptized by 1883 were freed slaves. This is not surprising, notes Heather Sharkey, for "[i]n many ways, ex-slaves, like orphans, were perfect candidates for conversion, since by definition they lacked families who were apt to drag them back to the Muslim community under threats of death." And disinheritance was not a disincentive either, as they had little property to lose. ${ }^{36}$

33 Muhafazat Asyut, Asyut fi 10 Sanawat (Cairo: Matba'at Nahdat Misr, 1962), 9; George M. La Rue, "The Capture of a Slave Caravan: The Incident at Asyut (Egypt) in 188o," African Economic History 30 (2002): 89.

34 Ahmed E. Elbashir, The United States, Slavery and the Slave Trade in the Nile Valley (Lanham: University Press of America, 1983), 61-66.

35 See, for example, PHS, RG 4O4, box 1, folder 3, Margaret Anna Smith Diary, August 25, 1878; RG 58, box 1, folder 8, Anna Thompson papers, Arabic manumission certificate; La Rue, "Capture of a Slave Caravan," 81-106.

36 Heather J. Sharkey, American Evangelicals in Egypt: Missionary Encounters in an Age of Empire (Princeton: Princeton University Press, 2008), 77. 
Missionary schools had also given shelter to freed slaves before. The Pressly Memorial Institute in Asyut had taken in three Sudanese girls from DarfurKeltuma, Assa, and Fanna - who had been "rescued by the pluck of some Soudaneese boys", according to Margaret McKown, founder of the school. The girls were placed in the boarding school, which gathered girls from area villages to train them in "common school education" and domestic work, and sent them back to their villages to minister to their own communities. At the school, the freed slaves received "the same training as the Egyptian girls" and were baptized three years after their arrival. But mobility for these freed African slave girls was more limited than those for Egyptian students. While the latter became teachers and Bible women, Keltuma and Assa (Fanna died prematurely) became matrons in the school and could be seen in a staff photograph taken in 189o. And although graduates of the school married Egyptian pastors, evangelicals, and teachers, the freed slaves joined a sisterhood of single women. ${ }^{37}$

When Baring approached American missionaries in Cairo to take in the twelve little black girls and train them as they wished, the women missionaries saw an opportunity. "Knowing their need of instruction, and hoping that some day teachers might be educated from their number for central Africa or the far 'upper country,' our mission consented," wrote Thompson. ${ }^{38}$ Evangelicals loathed the alternative: "For want of funds these girl would have been given over to the Roman Catholics, had not the Protestant missionaries consented to take them," reported The Christian, a British periodical. ${ }^{39}$ The readers of The Christian were asked to send in shoes and simple dresses to be forwarded to the freed slaves.

The twelve girls who moved from the Home for Freed Slaves in Faggala to the boarding school in Ezbekiah in March 1887 had not been consulted about their change of home and school. When they arrived at their new abode, they did not take kindly to the new routine and structure. As Thompson explained in her annual report, "Some had been in the home [for Freed Women Slaves] for several months. These came to us much prejudiced against me. Strange stories had been told them of how we would make them work, abuse them, and make them Christians" ${ }^{40}$ In short, the girls had already developed their own inform-

M.J. McKown, "Girls' School Assiout, Egypt," Women's Missionary Magazine vol. 3, no. 11 (June 189o):281; Earl Elder, Vindicating a Vision: The Story of the American Mission in Egypt, 1854-1954 (Philadelphia: United Presbyterian church of North America, 1958), 81.

38 Thompson, "Mission Work," 68; see also, Thompson's annual report quoted in Halima, 5.

39 The Christian (June 3, 1887) in Anti-Slavery Reporter (May-June 1887), 91.

40 Thompson's annual report quoted in Halima, 5. 
ation networks, most likely among the older freed slaves, and did not go quietly. In a letter to the Women's Missionary Magazine, Thompson elaborated on the girls' resistance: "without any knowledge of what their parents' religion was, they were all zealous for the Moslem faith, and the older ones were for a time refractory, because they heard we were going to baptize them". ${ }^{41}$ Having been converted by slavers or illegally enslaved as Muslims, the girls were old enough to have a sense of their own religious identities. And having been through much forced change already, they initially resisted another change.

The missionaries maintained that they did not use compulsion to convert but hoped that once surrounded by Christian teaching and practice, the African girls would prove receptive to the message. Their schooling included Arabic, English, Bible, catechism, housekeeping, and sewing, and some of their names are recorded in Thompson's class lists. ${ }^{42}$ By May, Thompson reported a "kindly spirit ... toward the Christian religion". ${ }^{43}$ The school cook, an unnamed freed Sudanese slave, played a key role in this transition, and started prayer meetings for the girls that summer. Within two years, one had been baptized and received into the church; two others were requesting baptism. ${ }^{44}$ One of those was Susan, who stood out as the most eager to learn about Christianity: "she prayed very earnestly that she and her companions might be used to carry the Gospel light to their people," wrote her teacher Adela Brown. Perhaps the girls thought Christian missionary work would be a way to get back home. Brown, who had a hard time seeing beyond colour, reported that Susan was ahead of her class in Bible and catechism. "Her bright, sparkling eyes made her attractive (though she was very black), and her diligence and ambition cheered the heart of her teacher." In the fall of 189o, however, Susan grew ill, and in April 1891, four years after she had entered the school, she was taken to the hospital. Until then, the missionaries had delayed her baptism; but when she asked again to be baptized, one of the missionaries spoke to her about it. "She passed away that night and was brought to the church the next day in her coffin. A few of us followed her to her resting place". ${ }^{45}$ The missionaries took her lack of fear in the face of death to be a sign of Christian faith and victory, a soul saved, not a life lost.

\footnotetext{
41 Thompson, "Mission Work," 68.

42 PHS, Anna Thompson Papers, RG 58, box 1, folder 10, list of pupils.

43 PHS, Anna Thompson Papers, RG 58, box 1, folder 4; Thompson to Sisters of Ohio, Cairo, May 27, 1887; Halima, 7 .

44 Thompson, "The Women's Work in Cairo," January 30, 1889 in Women's Missionary Magazine 2 (189o): 273.

45 Brown, "Susan Ameen," 167.
} 
Mortality among the twelve freed slave girls at the Ezbekiah School was high. One had arrived ill and died shortly thereafter; three others subsequently passed away, two of whom, according to Henrietta Harvey, had "given their hearts to Jesus and died trusting in him alone." Henrietta's husband, Dr Harvey, had overseen the baptism of those girls, recording it in his diary. Henrietta admitted that the missionaries used to think slave mortality was high due to improper care, but experience showed that freed blacks also suffered from high rates of consumption. Arduous treks at young ages across deserts or by sea inflicted injuries and illnesses on the girls that shortened their lives. Even as Henrietta wrote, one girl was ill in her home. In spite of the loss of life, the missionaries took the conversions of the freed slave girls as a sign of their success.

Five years after Baring had sent twelve girls to the missionaries, only eight remained alive: one was ill; one was helping in a school in Asyut; one was a Bible woman under Anna Thompson's supervision; one who had been a servant was now in school at her own expense; one was set to go to Aden to teach freed slave girls in the Scotch Free Church mission with another Abyssinian (a plan that was delayed due to scurvy and fever in that mission); and three were servants in missionary families. ${ }^{46}$ One of the remaining eight later became matron of the Ezbekiah Boarding School under Ella Kyle. ${ }^{47}$

Of the original twelve girls, American Presbyterian missionaries chose to highlight Halima's life story, memorializing her in a pamphlet. For them, her life was exemplary, in part because it remained intertwined with the lives of the missionaries who had raised her and their descendants. American missionaries in Egypt were a tight-knit group who, having left most of their kin in the USA, reconstituted themselves as a family. Sometimes they were interrelated, as offspring returned to the field after schooling to take up posts, and intermarriages between missionary families created second and third generations in the field. The missionaries appended the freed African slave girls to their families, or collective family, in roles familiar for African Americans in the USA: as servants, housekeepers, and nannies.

46 Henrietta Harvey, "Letters from Egypt," Cairo, October 7, 1892, in Women's Missionary Magazine 6, no. 5 (December 1892): 122; Thompson, "Women's Work," 273.

47 Elizabeth Kelsey Kinnear, She Sat Where They Sat: A Memoir of Anna Young Thompson of Egypt (Grand Rapids: Eerdmans, 1971), 40-42. 
When Halima finished her schooling, she went with a missionary family to Asyut, where she took care of the home and children. She subsequently worked in other American and Egyptian homes, and "became a general favorite and was known in the mission community from Khartoum to Alexandria." Her pamphleteer tells us, she had "the pride and dignity of her race" and performed her service with "grace". In short, she served the church community well and was well liked, "Friendly and cheerful in disposition, she always rejoined [sic] to meet old friends or to make new ones". ${ }^{48}$

Her life took a turn at about the age of twenty-five or so when she was called into a new sort of service. In 1904, the American Mission in Egypt opened a hospital for women and children in Tanta, the fourth largest town in Egypt. Located in the Delta, Tanta was known for its mawlid, an annual celebration of the birth of a saint that drew thousands of visitors annually and prior to abolition had included a brisk market for slaves. Halima and four of the other freed slave girls arrived in Tanta in response to a call from Lulu Harvey, daughter of Henrietta and Dr Harvey. Lulu had become superintendent of nurses at the new hospital, but could not find native nurses. She turned to "the black girls whom she had known ever since their arrival in Cairo" to train them as assistants. ${ }^{49}$

Lulu used a strategy similar to the one deployed by Clot-Bey, the French medical expert hired by Mehmet Ali to modernize the practice of medicine in Egypt seventy years earlier. When Clot-Bey opened the School for Midwives, his first recruits were slaves, followed by orphans and daughters of deceased military men, in short, girls who had no family on hand to veto this line of work. ${ }^{50}$ Likewise, Lulu turned to freed slave girls—now women-as recruits for her first class of nursing trainees. Although Egyptian women trained in the School for Midwives and worked as health care practitioners, few indigenous women worked in hospitals as nurses; it was not considered a suitable profession due to the gender mixing in a hospital.

Lulu Harvey trained Halima and the others, who came to Tanta with literacy in English and Arabic and the experience of having served in missionary institutions and American homes. Importantly for service in a missionary hospital, which coupled the provision of health care with proselytizing, Halima was also a Christian. "To the Christians she was a sister in Christ—one whose faith gave one courage. To Mohammedans she was a bright example of Christian cour-

\footnotetext{
48 Halima, 7-8.

49 Halima, 8.

$5^{\circ}$ A.B. Clot-Bey, Apercu General sur L'Egypte, vol. 2 (Paris: Fortin, Masson, \& C, 1840), 425428; see Kozma, "Women on the Margins," 69.
} 
tesy and kindness".51 Halima joined the local Evangelical Church, where she was a regular attendee, and was considered a "born nurse". When the American hospital in Tanta was closed at the outbreak of World War I, Halima found employment in the English mission hospital in Cairo. She then entered the School for Midwives (at about the age of forty), earning her certificate and taking up a job in a government hospital. Upon the reopening of the American hospital in Tanta in 1919, at which time it was expanded into a general hospital, she returned. There she served private patients, including ill American missionaries. The latter gave testimony of her tender care, "the comfort of her hand", her "gentle" touch in giving back rubs and baths, and the ease with which she turned bodies. ${ }^{52}$

Yet missionaries and local Christians were not her only social circles. Halima had links with the small Ethiopian community in Cairo, through whom she learned definitively of her parents' deaths. Perhaps she had kept alive a hope of returning home to them one day. In 1928, at about the age of fifty-two, she retired from work at the hospital and married a younger Ethiopian man living in Cairo, finally settling down. The missionary community feared the younger man was after her money and initially begrudged her the companionship and intimacy that marriage might bring. Having worked for half a century and lived in other peoples' homes, she established her own home and balcony garden. At the same time, she rekindled ties with some of her "sisters", the freed slaves from boarding school days. When one was widowed and unable to care for her daughter, Halima took the girl in and raised her as her own. "The joy and pride of motherhood became hers in this girl," her pamphleteer wrote. The girl later became the wife of the Ethiopian ambassador to the USA. With a "daughter" to support, Halima went back to work as a nurse, caring for the mother of one of the missionaries. In her leisure in the invalid's home, she read from her Arabic Bible and the Women's Missionary Magazine. But the nurse was losing strength and was sent to Tanta Hospital for testing. There she was diagnosed with terminal cancer and died in August 1934 at about the age of fifty-eight in the hospital where she had served for decades. ${ }^{53}$

Her pamphleteer concluded, "It had been no small responsibility to take into a little school family twelve wild orphans of another race and color. Infinite patience and Christian love were lavished on the child Halima. How gloriously

51 Halima, 8-9.

52 Halima, 8-9.

53 Halima, 10-14. 
she repaid the sacrifice." Her devotion, service, and "victorious testimony in the hour of death" reaffirmed the missionaries' decision to take in the freed slave girls sent by Baring. ${ }^{54}$ Of all the freed African slave girls, Halima's life most closely followed the missionaries' script for a life of service, at least in their telling. Halima's perspective remains elusive.

\section{$5 \quad$ Conclusion}

Egyptian slave traders and owners, British abolitionists and colonial officials, and American missionaries all had plans for the twelve African girls. Traders looked to make a quick profit, owners needed household labour, abolitionists sought to rescue them from forced servitude, colonial officials planned to refashion them as wage earners, and missionaries dreamt of converts, church workers, and saved souls. Given their high rates of conversion and the occupations they took up, the girls fulfilled Anna Thompson's original hopes for them. Of those placed in the school, a third died prematurely but not before accepting Christianity, which the missionaries took as a sign of their success. Others survived to carve out lives within set parameters, serving in missionary schools, hospitals, and homes. The girls were tracked into lives of service for the missionary community in the lower rungs, or as teachers for other Africans, rather than in more prestigious church professions. But they occasionally challenged the parameters, with one funding her own further education, another resisting the pressure to convert, and a few establishing families, showing that the girls and women they became sought to shape their own lives.

As far as we know, none of the twelve went or were sent back home to their own country to find their families, though that is a return passage that some freed slaves took. Those running manumission boards and refuges found this journey impractical and gave freed slaves little support to return home. Only a few started their own families. Given their long hours of domestic service in missionary homes, as matrons in boarding schools, or nurses in hospitals, they spent large portions of their lives raising and caring for other peoples' children rather than conceiving and raising their own. Their work was productive, not reproductive, and they left few descendants who might carry the collective memory of slavery and remember their individual stories. Instead, they lived mostly single, and sometimes isolated, lives. They retained bonds 
with the missionaries who had raised and schooled them and for whom they worked. They also tapped into immigrant and religious networks, and created links of their own. In whatever time they had spent together in the rough passage to Egypt through Jidda or Asyut or some other route, in the Home for Freed Women Slaves, and in the Ezbekiah Boarding School, these Africans developed close attachments to one another. They studied and worked together, and turned to one another in times of need. Their lifelong bonds helped to see them through periods of transition, sickness, and death. In the absence of kin, they spoke of one another as "sisters" and created a "feeling of family fellowship" that lasted a lifetime..$^{55}$ These networks eased their alienation in a society that placed family ties at the centre but in which they stood out as racially other.

The experience of these twelve freed African slaves shows that the end of slavery was neither swift nor painless. Caught in the last throes of the slave trade almost a decade after it had been banned, the twelve were forcibly separated from their parents; smuggled in harsh conditions overland and by boat to Egypt; faced disease and sometimes early death; were pressured, sometimes repeatedly, to adopt a new religion and name; worked in the homes, schools, and hospitals of a group that considered them sisters in Christ but racially inferior; and had little opportunity to create their own families. The impact of the institution of Egyptian slavery on the African societies from which these and other children and adults were taken was devastating as well. The lives that emerge from missionary and abolitionist sources are fragile and fragmented, but the sources begin to give faces, names, and voices to these freed slaves.

\section{Bibliography}

Aysut, Muhafazat. Asyut fi 10 Sanawat. Cairo: Matbaat Nahdat Misr, 1962.

Baer, Gabriel. "Slavery in Nineteenth Century Egypt." Journal of African History 8, no. 3 (1967): 417-441. Reprinted as "Slavery and Its Abolition." In Studies in the Social History of Modern Egypt, chapter 10. Chicago: University of Chicago Press, 1969.

Baron, Beth. Egypt as a Woman: Nationalism, Gender, and Politics. Berkeley: University of California Press, 2005.

Brown, A.A. "Susan Ameen," Cairo, Nov. 1891. Women's Missionary Magazine 5, no. 6 (Jan. 1892). 
Clot-Bey, A.B. Apercu General sur L'Egypte. Volume 2. Paris: Fortin, Masson, \& C., 1840 ,

Crewe, E. “The Slave Trade in Egypt," Cairo, April 9, 1886. Anti-Slavery Society (May-June 1886).

Elbashir, Ahmed E. The United States, Slavery and the Slave Trade in the Nile Valley. Lanham: University Press of America, 1983.

Elder, Earl. Vindicating a Vision: The Story of the American Mission in Egypt, 1854-1954. Philadelphia: United Presbyterian church of North America, 1958.

Erdem, Y. Hakan. Slavery in the Ottoman Empire and Its Demise, 1800-1909. New York: St Martin's Press, 1996.

Halima-The Gentle One. Pittsburgh: Women's General Missionary Society, United Presbyterian Church of North American, n.d.

Harvey, Henrietta. "Letters from Egypt," Cairo, October 7, 1892. In Women's Missionary Magazine 6, no. 5 (Dec. 1892).

Hilal, Imad. Al-Raqiq fi Misr fi al-qarn al-tisa' 'ashar. Cairo: al-'Arabi, 1999.

Hilal, Imad. "The Anti-Slavery Movement in Egypt in the Nineteenth Century: Between Shari'a and Practice." (Paper presented at a workshop on "Race and Slavery Between the Middle East and Africa." cuny Graduate Center, April 23, 2004).

Hunwick, John and Eve Troutt Powell. The African Diaspora in the Mediterranean Lands of Islam. Princeton: Markus Wiener Publishers, 2002.

Hunwick, John. "The Religious Practices of Black Slaves in the Mediterranean Islamic World." In Slavery on the Frontiers of Islam, edited by Paul E. Lovejoy, 149-171. Princeton: Markus Wiener Publishers, 2004.

Kinnear, Elizabeth Kelsey. She Sat Where They Sat: A Memoir of Anna Young Thompson of Egypt. Grand Rapids: Eerdmans, 1971.

Kozma, Liat. "Women on the Margins and Legal Reform in Late Nineteenth-Century Egypt, 1850-1882." PhD diss., New York University, 2006.

La Rue, George M. "The Capture of a Slave Caravan: The Incident at Asyut (Egypt) in 188o." African Economic History 30 (2002).

McKown, M.J. “Girls' School Assiout, Egypt.” Women's Missionary Magazine vol. 3, no. 11 (June 189o).

Mowafi, Reda. Slavery, Slave Trade and Abolition Attempts in Egypt and the Sudan 18201882. Stockholm: Esselte Studium, 1981.

Pursley, Sara. "From Civil War to Civilizing Mission: American Military Officers in the Egyptian Service, 1869-1879." (Paper presented at a workshop on "Race and Slavery Between the Middle East and Africa," cunY Graduate Center, April 23, 2004).

Robinson-Dunne, Diane. The Harem, Slavery and British Imperial Culture: Anglo-Muslim Relations in the Late Nineteenth Century. Manchester: Manchester University Press, 2006. 
Sharkey, Heather J. American Evangelicals in Egypt: Missionary Encounters in an Age of Empire. Princeton: Princeton University Press, 2008.

Starbuck, Charles C. “Theological and Religious Intelligence.” The Andover Review (May 1889).

Thompson, Anna. “The Women's Work in Cairo." (Jan. 30, 1889). Women's Missionary Magazine 2 (1890).

Thompson, Anna Y. “Mission Work in Egypt." Women's Missionary Magazine 5, no. 3 (October 1891).

Toledano, Ehud R. Slavery and Abolition in the Ottoman Middle East. Seattle: University of Washington Press, 1998.

Toledano, Ehud R. As If Silent and Absent: Bonds of Enslavement in the Islamic Middle East. New Haven: Yale University Press, 2007.

Troutt Powell, Eve M. A Different Shade of Colonialism:Egypt, Great Britain, and the Mastery of the Sudan. Berkeley: University of California Press, 2003.

Tucker, Judith E. Women in Nineteenth-Century Egypt. Cambridge: Cambridge University Press, 1985 .

Whately, Mary L. Letters from Egypt to Plain Folks at Home. London: Seeley, Jackson, \& Halliday, 1879 .

\section{Anti-slavery Reporter Editions}

"Egypt." March-April 1893.

January 1885 .

August 1885 .

Scott-Moncrieff, C. Letter, Cairo, October 6, 1885. December 1885 .

Crewe, E. "The Slave Trade in Egypt." Cairo, 9 April 1886. May-June 1886.

Scott-Moncrieff, C.C. “The Treasurer's Report-1886.” May-June 1886.

May-June 1886.

Du Port, M.S.P. "Report of the Cairo Committee of the Year 1886." March-April 1887.

"The Christian." (June 3, 1887) May-June 1887.

\section{Rhodes House Library}

BFAAPS, S22, G25, Africa, No. 4 (1887). Correspondence Respecting Slavery in Egypt, Inclosure 2 in No. 1, Lieutenant-Colonel Schaefer to Captain Crawford, Commandant, Suez (October 25, 1886).

BFAAPS, S22, G25, Africa, No. 4 (1887). Correspondence Respecting Slavery in Egypt, Inclosure 1 in No. 1, Schaefer to Sir E. Baring, Cairo (December 16, 1886).

B FAAPS, S22, G25, Africa, No. 4 (1887). Inclosure 3 in No. 1, Schaefer, "Etat Nominal des Esclaves importes pendant le Saison du Pelerinage de 1886." 


\section{Presbyterian Historical Society (PHS)}

Anna Thompson Papers, RG 58, box 1, folder 4, Notebook: Red Letter Days.

Anna Thompson Papers, Arabic manumission certificate, RG 58, box 1, folder 8 .

Anna Thompson Papers, List of pupils, RG 58, box 1, folder 10.

Anna Thompson to Sisters of Ohio. Cairo, May 27, 1887.

Margaret Anna Smith Diary, RG 404, box 1, folder 3, August 25, 1878. 